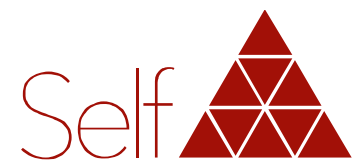

Revista do Instituto Junguiano de Săo Paulo

\title{
O corpo e a simbologia arquetípica no movimento Taki Onkoy nos Andes no fim do século XVI d.C. ${ }^{1}$
}

\section{Sandra MORALES MERCADO}

São Paulo/SP, Brasil.

\begin{abstract}
${ }^{1}$ Trabalho originário da monografia: "O retorno ao mito e a busca da transformação através do movimento Taki Onkoy, um olhar junguiano“, sob orientação de José Jorge de Morais Zacharias, para obtenção do título de especialista em terapias corporais e artísticas baseadas na psicologia analítica pela Universidade Paulista - Unip.
\end{abstract}

Conflito de interesses:

A autora declara não haver nenhum interesse profissional ou pessoal que possa gerar conflito de interesses em relação a este manuscrito.

Financiamento:

não houve

\section{Resumo}

Durante os anos seguintes à conquista espanhola na América, surgiram vários fenômenos militares, políticos, civis, religiosos e sociais. Historiadores e antropólogos dedicaram-se à admirável tarefa de reunir fontes, checar dados e estudar depoimentos sobre esses fenômenos. Dentro dessa literatura, encontramos o movimento Taki Onkoy, normalmente inserido nas rebeliões ocorridas como reação dos indígenas ao domínio espanhol. Mas o movimento Taki Onkoy não era uma rebelião como as outras que surgiram nesse período, o movimento Taki Onkoy tornou-se a manifestação mais dramática da noção andina do sagrado e do poder dos sacerdotes andinos, que se lançaram na busca pela transformação e reestruturação da consciência. Este artigo teve como objetivos aprofundar o conhecimento da experiência religiosa coletiva do movimento Taki Onkoy e compreender seus símbolos arquetípicos e origem psíquica. A partir da teoria junguiana, abordou-se o encontro de dois mundos e buscou-se entender os complexos processos psicológicos e corporais que giravam em torno do movimento Taki Onkoy. A psicologia analítica contribuiu para compreender os momentos históricos da violência e do trauma em que um conjunto de símbolos sociais foi aniquilado e o ser humano retornou desesperadamente à procura de seu próprio imaginário, de seus mitos e de sua própria essência, usando para isso os símbolos e o corpo.

\section{Descritores}

Psicologia junguiana, ritos de passagem, deuses.

Recebido: 4 abr 2020; $1^{a}$ revisão: 15 jun 2020; Aprovado: 24 jul 2020; Aprovado para publicação: 2 nov 2020 


\title{
The body and archetypal symbolism in the Taki Onkoy movement, in the Andes, by the end of the XVI century AD
}

\begin{abstract}
During the years that followed the Spanish conquest of America, various military, political, civil, religious and social phenomena emerged. Historians and anthropologists devoted themselves to the admirable task of gathering sources, checking data and studying testimonials about these phenomena. Within this literature, we find the Taki Onkoy movement, usually inserted among rebellions occurred as a reaction of the indigenous people to the Spanish domination. However, unlike any other rebellions of that period, the Taki Onkoy movement became the most dramatic manifestation of the Andean notion of the sacred and of the power of the Andean priests, who threw themselves into the search for a transformation and restructuring of the awareness. This article aimed at deepening the knowledge of the collective religious experience of the Taki Onkoy movement, and understanding its archetypal symbols and psychological origin. Based on the Jungian theory, it was approached the encounter of two worlds, seeking to understand the complex psychological and physical processes around it. Analytic psychology contributed to understand the historical moments of violence and trauma during which a set of social symbols was annihilated, and human beings desperately returned to search for their own imaginary, their myths and their own essence, by using symbols and the body.
\end{abstract}

\section{Descriptors}

Jungian psychology, rites of passage, gods.

\section{El cuerpo y la simbología arquetípica en el movimiento Taki Onkoy en los Andes en el fin del siglo XVI d.C.}

\section{Resumen}

Durante los años posteriores a la conquista española en América, surgieron varios fenómenos, políticos, civiles, religiosos y sociales. Historiadores y antropólogos se dedicaron a la admirable tarea de reunir fuentes, comprobar datos, y estudiar testimonios sobre esos fenómenos. Dentro de esa literatura, encontramos el movimiento Taki Onkoy, normalmente incluido en las 
rebeliones ocurridas como reacción de los indígenas al dominio español. Pero el movimiento Taki Onkoy no era una rebelión como las otras que surgieron en ese período, el movimiento Taki Onkoy se convirtió en la manifestación más dramática de la noción andina de lo sagrado y del poder de los sacerdotes andinos, que se lanzaron en busca de la transformación y reestructuración de la consciencia. Los objetivos de este artículo fueron profundizar el conocimiento de la experiencia religiosa colectiva del movimiento Taki Onkoy y comprender sus símbolos arquetípicos y origen psíquica. A partir de la teoría junguiana, se abordó el encuentro de dos mundos y se procuró entender los complejos procesos psicológicos y corporales que giraban alrededor del movimiento Taki Onkoy. La psicología analítica contribuye para comprender los momentos históricos de violencia y de trauma, en los cuales se aniquiló un conjunto de símbolos sociales, y la vuelta desesperada del ser humano a buscar su propio imaginario, sus mitos y su propia esencia, usando para eso los símbolos y el cuerpo.

\section{Descriptores}

Psicología junguiana, rituales de pasaje, dioses.

\section{O Taki Onkoy}

Taki Onkoy poderia ser o único caso, dentro da tradição andina, em que a divindade não se expressa em um objeto (pedra, lago), animal (falcão, condor) ou fenômeno natural (relâmpago), mas no corpo dos homens e sua dança (Millones, 2007, p. 204).

O movimento Taki Onkoy nasceu por volta de 1560 em Huamanga (Ayacucho, Peru). O termo quíchua "Taki Onkoy" significa "doença da dança"; também conhecido como "Ayra", em aymara, que significa "loucura ou desejo de enlouquecer" (Curatola, 1987).

Após quase 30 anos do estabelecimento dos espanhóis e da destruição do físico e do espiritual dos indígenas, a população conquistada começou a aceitar que os europeus não abandonariam facilmente os territórios conquistados. Foi nesse momento que os sacerdotes religiosos andinos do Taki Onkoy não encontraram melhor alternativa do que a criação de duas sociedades: uma católica espanhola e uma andina, com suas próprias tradições e crenças. Essa proposta ameaçava as ambições políticas espanholas e também as ambições da Igreja Católica, que deveria ter o controle total do povo indígena, assim, ela foi categoricamente rejeitada pelas autoridades espanholas.

É interessante notar que essa visão andina de uma sociedade dividida foi projetada em diferentes áreas, por exemplo, na abordagem das doenças e seus tratamentos e na competição entre curandeiros andinos e espanhóis (Brosseder, 2018). 
A necessidade de dividir a sociedade, por parte dos religiosos andinos do movimento Taki Onkoy, foi uma reação ao caos em que toda a comunidade andina estava afundando: seu modo de vida, seu domínio sobre a terra, seus deuses e, principalmente, as mortes por doenças. Desanimados com a confusão na qual as ordens cósmica, política e social estavam imersas, os religiosos e os indígenas em geral sentiram-se impotentes e culpados por terem abandonado seus deuses (Rostworowski, 2017). Portanto, a ideia subjacente ao Taki Onkoy foi a de restaurar uma comunidade sem injustiça ou doenças e de acordo com velhas crenças e com o velho estado de coisas.

Como aponta Millones (2007), o Taki Onkoy não buscou a recuperação absoluta do passado, como costumava acontecer nas batalhas entre conquistadores e conquistados, pelo contrário, anunciou a transformação desse passado e sua adaptação ao novo processo histórico que estava enfrentando.

O Taki Onkoy então rejeitou tudo o que era estranho ao mundo andino sem incitar a rebelião armada. Segundo Millones (2007), enquanto nasciam várias rebeliões da resistência armada contra os conquistadores, lideradas pela nobreza incaica, o movimento Taki Onkoy contava com líderes regionais e conceitos de transformação espiritual. Para estes líderes, as huacas estavam com fome e com raiva porque o povo indígena havia sido batizado na religião católica.

O termo "huacas" refere-se às divindades do mundo andino. Geralmente associadas às montanhas, aos lagos, às cavernas, as huacas eram divindades que se transformavam ou desapareciam conforme os fenômenos naturais acontecessem ou de acordo com as histórias que se entrelaçavam em torno de certos cenários andinos e costeiros. Toda huaca era sagrada e, neste extenso grupo, podem ser incluídos os santuários, ídolos, templos, sepulturas, múmias, lugares sagrados, animais, estrelas das quais os ayllus (famílias) ou clãs acreditavam descer, seus próprios antepassados. Atualmente o nome huaca também é usado para designar um lugar arqueológico.

Rostworowski (2017) nos explica, por meio de sua análise dos mitos andinos, que dois grupos de huacas se distinguiam e se complementavam: o masculino e o feminino. As divindades masculinas (Wiracocha, Illapa, Tunupa, Amaru) estão relacionadas aos fenômenos naturais que se tentava controlar por meio de ritos e de oferendas. Já as femininas (Pachamama, Mamacocha, Urpay Huachac, Mama Raiguana) eram derivadas de deusas-mães, nutridoras como a terra, e relacionadas à comida e à subsistência do homem.

Depois de quase 30 anos após a chegada dos conquistadores, o povo andino estava desaparecendo em razão de doenças, epidemias e mortes, que realmente os dizimavam. Para eles, foi o anúncio claro de um fim. Os povos indígenas metaforizaram essa situação frustrante como se tivessem sido afetados por uma doença total. $\bigcirc$ movimento expandiu-se rapidamente. 
De acordo com a documentação histórica do Taki Onkoy, qualquer pessoa poderia ser mensageira das huacas, destacando-se várias mulheres. Para pregar, a pessoa não precisava ser um sacerdote religioso - qualquer indígena possuído pelas huacas poderia fazê-lo. Essa possessão é descrita por Curatola (1987):

[...] E também houve muitos que, dominados por sequestros autodestrutivos, infligiram mutilações horrendas ou acabaram se matando ou se afogando como um sacrifício supremo aos seus deuses. $\bigcirc$ homem possuído, que sobreviveu ileso à fase aguda da fúria mística, uma vez terminada a crise, caiu no chão exausto e, para aqueles que o abordavam cautelosamente perguntando o que havia acontecido, ele respondeu que uma certa huaca havia se apossado de seu corpo. Os índios, então, reverentes e medrosos, levantaram-no e o carregaram nos braços para um local apropriado, onde construíram uma pequena habitação com paredes feitas de cobertores e tapetes. Depois de pintar o rosto de vermelho, trouxeram-lhe oferendas de milho, chicha, molle, pasta de cal preparada com quinoa, animais, tecidos, prata e muitas outras coisas, adorando no huaca encamado (pp. 102-103).

Os profetas do Taki Onkoy assumiram a tarefa de anunciar que o mundo deveria girar, e a primeira tarefa a ser realizada seria a ressurreição, reincorporação e revitalização das huacas, lideradas por duas importantes huacas: a Huaca Titicaca e a Huaca Pachacamac (Millones, 2007).

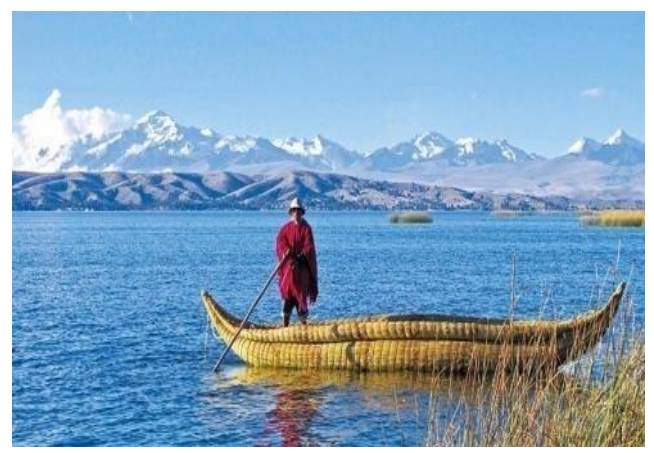

Figura 1. Lago Titicaca.

Fonte: https://es.wikipedia.org/wiki/lagotiticaca 


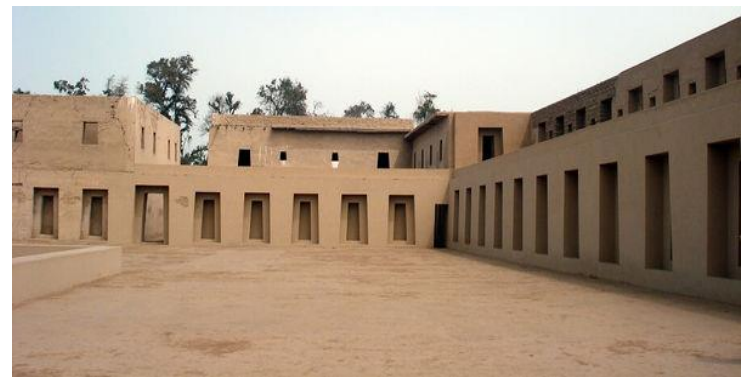

Figura 2. Complexo arqueológico de Pachacamac, Lurín. Fonte: https://es.wikipedia.org/wiki/Pachacamac

Segundo os religiosos andinos do Taki Onkoy, essas e outras huacas andavam pelo ar, dando ordens para lutar contra Deus e, assim, acabar com o tempo do cristianismo. Os oficiais religiosos exortaram o povo indígena a não acreditar no deus católico, nem nos mandamentos, nem nos símbolos cristãos. Dentro desse conjunto de regras, era de importância transcendente não consumir comida castelhana, não usar roupas europeias e não participar de cerimônias, danças escatológicas e rituais (Cavero, 2001).

O Taki Onkoy mostrou-se, então, uma tentativa suprema de reconstituir a ordem andina, que não se expressou diretamente em rebeliões ou movimentos armados, mas em práticas simbólicas-religiosas que incluíam canções e danças (Montani e Paez, 2008).

Por esse motivo, a parte mais visível e duradoura desse movimento são as canções e as danças frenéticas expressas nos corpos, nas quais fórmulas rituais ou mensagens de caráter histórico religioso foram repetidas incansavelmente.

\section{O corpo, refúgio das huacas}

A crônica de Guamán Poma de Ayala (1615) demonstrou que as formas de danças e canções coreográficas (taquis ou tussuy) eram infinitas no mundo andino. Também sabemos pelos diferentes historiadores que as danças ritualísticas usando o corpo como instrumento de espiritualidade eram uma característica importante da religião inca, assim como de outras religiões antigas.

Tanto no período inca quanto para os povos que os antecederam, as danças estavam associadas à agricultura, à fertilidade, ao culto aos antepassados, às cerimônias de iniciação ou ao xamanismo como cura para os doentes. Portanto, entende-se que a dança apresentava um caráter sagrado e ritualístico para os andinos. 
No entanto, na história religiosa de todo o mundo, manifestações de êxtase ou exaltação emocional têm sido objeto de frequentes rejeições e estigmatizações.

Na Antiguidade, o deus grego Dioniso é um exemplo claro da estigmatização das danças e do êxtase prolongado. Dioniso era filho de Zeus e da humana Sêmele (em outra versão, da deusa Perséfone), um deus difícil de classificar com apenas um atributo: ele era o deus do vinho, do excesso, do êxtase místico, da loucura e representava também a força regeneradora da natureza (Vernant, 1999).

Apesar muitos autores o considerarem uma divindade ambígua, Dioniso era tratado como um deus tão importante como os outros deuses do Olimpo. Porém, seus cultos, que costumavam levar as pessoas a um estado de êxtase e transe, banhadas em vinho e dança, provocaram discordâncias a ponto de serem banidos e Dioniso passou então a ser considerado um deus menor. Tal situação estaria relacionada a questões morais, como a estigmatização dos dançarinos como selvagens e impulsivos.

No entanto, acreditamos que os mitos e a simbologia em torno da figura de Dioniso são muito mais extensos e importantes do que o lugar que ele ocupava no panteão grego ou do que o número de mortais que o adoravam. Encontramos analogias fortes com os rituais andinos e com a força corporal do Taki Onkoy: Dioniso representa a explosão mística pela dança, pelo excesso, através do espelho onde a alma humana se reflete no corpo (Hard, 2008).

Dioniso morreu e nasceu de novo, ele foi transformado. Se focarmos em como Dioniso chegou a este mundo, ele simbolizaria divisão ou fragmentação, uma ideia central para o pensamento arquetípico. Os povos indígenas do Taki Onkoy experimentaram a fragmentação literal de suas huacas e passaram por uma fragmentação de suas almas. Para reintegrar ambos, os corpos foram utilizados como uma ponte para estabelecer contato com a dimensão arquetípica e na busca pelo Self.

Hard (2008) explica como Dioniso representa o renascimento. Porém, para renascer é necessário morrer e, por esse motivo, ele também é o deus da morte. Na fragmentação de Taki Onkoy, as mortes interna e externa foram reproduzidas em um círculo fechado e as forças da vida foram afirmadas, reagrupando-se no último bastião: o corpo.

Os sacerdotes do Taki Onkoy lutavam por meio de suas danças e rituais para se libertarem do opressor. $\bigcirc$ corpo social do mundo andino foi marcado por uma forma de repressão alheia e desconhecida do próprio discurso da sociedade indígena. Da mesma forma, Dioniso quis libertar os habitantes de Tebas das opressões a que estavam sujeitos.

Tanto no ritual dionisíaco como no Taki Onkoy, a música, a dança, a doença e a irmandade tinham um papel relevante como elemento terapêutico e purificador, realizando uma catarse da alma. No Taki Onkoy, as danças comunitárias eram caracterizadas pela natureza selvagem extática. 
Na história, encontramos vários exemplos de como as danças coletivas mobilizaram fenômenos inconscientes que atingiam a fusão das consciências individuais em um grupo inteiro. Os laços de pertencimento eram fortalecidos e mantinham as pessoas juntas, retornando ao corpo. No Taki Onkoy, as práticas ritualísticas adotadas com base nas antigas tradições tornaram-se uma manifestação das energias internas pelas quais a comunidade e a divindade uniam-se.

Assim como as características dessas danças rituais não pertencem apenas ao mundo andino, elas também não são exclusivas da era Taki Onkoy. No Dicionário Quechua-Espanhol, de González Holguín (1952), os termos relacionados à dança e à música são abundantes: danças com máscaras, danças realizadas em rituais específicos como fertilidade, danças e canções para funerais, danças e canções de guerra e de vitória, cantores de fábulas, canções de ninar entre outros.

Rostworowski (2017) explica que antes do Taki Onkoy, no mundo andino, as danças duravam vários dias, eram realizadas no âmbito dos ritos agrários e tinham caráter propiciatório; sua execução acontecia principalmente para adorar as huacas que garantiriam seu apoio para a obtenção de boas colheitas e chuvas.

Além de sua importância ritual, algumas danças também constituíam cerimônias de unificação do grupo e de controle social - recorrendo à figura legitimadora dos antepassados, permitiam às autoridades locais regular as relações sociais dentro de suas comunidades, mantendo normas morais tradicionais e seu poder político.

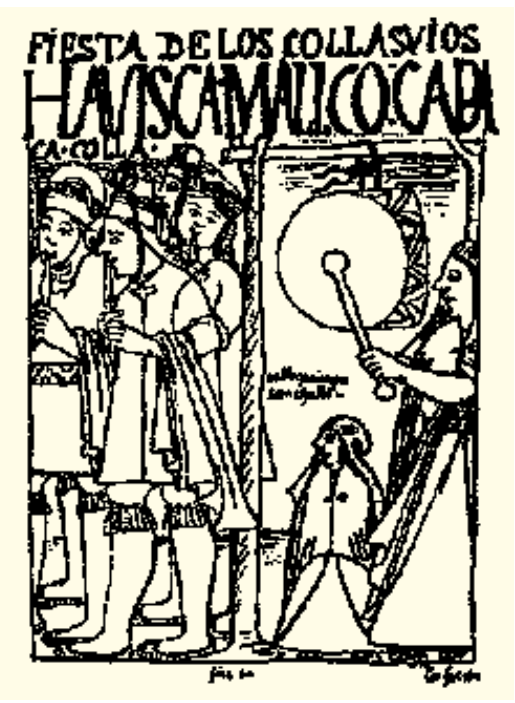

Figura 3. Festa andina. Gravado de Guaman Poma de Ayala.

Fonte: https://es.m.wikipedia.org/wiki/Archivo:Fiesta_de_los_Collasuyos.jpg 
O termo quíchua "taqui" possivelmente era usado desde muito antes do século XVI d.C. para se referir a danças indígenas que incluíam dança, canto e, na maioria dos casos, o uso de um instrumento musical como o pincullo (flauta) ou o tinya (tamborcillo). Mas, parece importante acrescentar que González Holguín (1952) traduz em seu dicionário as palavras quíchuas "Taquini" ou "Taquicuni" com a frase: cantar apenas sem dançar ou cantar dançando.

Se o movimento Taki Onkoy era conhecido como dança do desespero (Curatola, 1987), a tradução de González Holguín nos leva a concluir que as danças desses rituais não eram com uma coreografia ou dança definida. Eram danças extasiadas de grupo cujo objetivo era funcionar como um depósito das huacas e que podiam se expressar através do corpo; portanto, tratava-se de uma experiência psíquica que ajudava os indígenas a evocar no inconsciente as forças arquetípicas e isso lhes permitia resistir ao invasor e restaurar na psique o poder perdido.

Ao aderir a esses rituais, além de prometer o estabelecimento das antigas divindades, os oficiais religiosos do Taki Onkoy também prometeram ao povo andino a restauração da boa saúde e da abundância de alimentos. $\bigcirc$ movimento Taki Onkoy abrangeu, portanto, não apenas a urgência de curar - trauma da conquista e da derrota de seus deuses, mas também as necessidades muito tangíveis do corpo.

Millones (2007, p. 23) nos dá acesso ao texto original de Cristóbal de Molina, sacerdote católico que registrou o movimento Taki Onkoy no seu livro "Fábulas e ritos dos incas" (1575), onde essa nova forma de messianismo corporal foi proclamada:

Agora todos eles se levantaram para batalhar [o deus cristão] e vencer, e que as referidas guacas não estavam mais incorporadas em pedras ou árvores ou nas fontes, como nos dias dos ynga [Incas], mas antes entraram no corpos dos Yndios [sic] e os fizeram falar, e a partir daí começaram a tremer, dizendo que tinham as guacas em seus corpos (Molina, 1575/1947, p. 80 citado por Millones, 2007, p. 23).

Entendemos então que as huacas despojadas de seus templos e com suas cerimônias públicas proibidas pelos conquistadores espanhóis, refugiaram e se manifestaram no corpo dos crentes. O corpo tornou-se o templo vivo e o vetor de fúria diante das forças opressivas.

Os rituais do movimento Taki Onkoy tinham uma série de regras (Rostworowski, 2017). Antes da sua realização, cumpria-se períodos de cinco dias de abstinência sexual e nutricional, com a proibição absoluta do consumo de refeições com sal e pimenta ou qualquer outra variedade de milho, sendo a dieta baseada quase que exclusivamente em uma chicha especial com baixo teor alcoólico; também era importante não comer comida espanhola. Nenhuma dessas restrições ou as danças em si eram reservadas apenas para os sacerdotes religiosos, todos eram participantes ativos. 
Na estrutura religiosa dos incas, a expressão das huacas no corpo parece ter sido um poder reservado apenas aos sacerdotes andinos e, provavelmente, aos incas. $\bigcirc$ status de mensageiro dos deuses correspondia a um status social privilegiado (Montani e Paéz, 2008). Com o movimento Taki Onkoy, existiu uma espécie de descentralização do poder religioso oficial, o poder de lidar com o sagrado tornou-se popular, diferente do que acontecia na religião inca. Os adeptos do movimento adquiriram um poder desafiador, ao transformar seus corpos em um refúgio para as huacas, e correram o risco de morrer devido à incansável perseguição por parte dos extirpadores de idolatrias desse período.

Por seu lado, a religião cristã extremamente punitiva, com códigos morais externos que viam o diabo em toda parte e em qualquer ato, teve como característica uma série de renúncias à expressão corporal e libidinal. Essa repressão provocou uma resposta dos corpos, e os povos indígenas dançavam na atraente clandestinidade e na tentativa de alcançar algo que estava além deles mesmos.

A dança extática, especialmente aquelas em que as huacas Titicaca e Pachacamac dominavam os corpos, era um canal para as forças inconscientes deslizarem, com a ajuda de antigas práticas rituais, para uma forma organizada. Simbolicamente, elas poderiam estar relacionadas ao sonho arquetípico de uma idade de ouro (ou o paraíso). Segundo Jung (1961/2016), "Cada sociedade tem suas próprias concepções de caráter arquetípico sobre o paraíso ou uma idade de ouro, que se acredita já ter existido e que voltará novamente a existir" (p. 108). Como os corpos são os refúgios dos últimos vestígios de identidade, a dança poderia ser interpretada como uma forma de regressão coletiva inconsciente ao que parece ser um ato autêntico de transformação individual e coletiva, com base na criatividade primordial do movimento.

De Almeida (201 1, p.35) nos diz:

Em momentos profundos de integração e transcendência, essa experiência é estendida para os chamados estados alterados de consciência, êxtase místico e experiências de iluminação. $\bigcirc$ fato de estar profundamente enraizado no corpo permite a experiência de ir além e perceber o mundo através das aparências e sentir-se um com ele.

É importante mencionar que os rituais de dança extática coletiva são formas pelas quais o corpo torna-se particularmente intenso, o veículo prático, direto e eficaz da comunicação religiosa, assim concebido em várias religiões do mundo. O corpo dos povos indígenas do Taki Onkoy fundia-se com a divindade, dando origem ao sentimento de salvação, de libertação espiritual e de poder de transformação próprio dos deuses. Os deuses tornavam-se oradores através do corpo. 


\section{A simbologia arquetípica das grandes huacas}

Há uma tendência histórica de ver as funções dos diferentes curandeiros, feiticeiros ou xamãs andinos, como são chamados, como aquelas de um médico ou professor. No entanto, as funções dos sacerdotes andinos do Taki Onkoy foram muito além, seu fim não era mais a cura ou a instrução de conhecimento, mas o próprio despertar de conteúdos simbólicos do inconsciente.

Se considerarmos a essência do inconsciente como impessoal, pelo menos como tendo um espectro que vai além da personalidade e da individualidade, podemos falar da possibilidade de experimentar objetivamente movimentos psíquicos que não tenham uma localização pessoal específica, que se estendam para além do corpo de si, do mundo conhecido, e que, portanto, tenham muitos tipos de manifestação.

A psicologia analítica define imagem arquetípica como todas aquelas imagens e fantasias oníricas que correlacionam com semelhança especial motivos universais pertencentes a religiões, mitos, lendas. São imagens ancestrais autônomas derivadas dos arquétipos. Em um nível pessoal, os arquétipos manifestam-se por meio dos complexos e, no nível coletivo, como características de todas as culturas. $\bigcirc$ arquétipo está presente em todo produto cultural ou ideológico do ser humano (Jacobi, 2016).

Jung chama o arquétipo de símbolo que libera energia relacionada a uma imagem coletiva (Campbell, 2008). Mas, o arquétipo também pode ser usado como um elemento ou base conceitual para entender e explorar todos os tipos de experiências nas quais a função criativa da imaginação está presente.

Do acordo com Jacobi (2016) quando o conteúdo humano - coletivo do arquétipo - entra em relacionamento com a consciência, o arquétipo adquire corpo, torna-se representável e, somente então, torna-se uma imagem verdadeira, a imagem arquetípica: o símbolo.

O símbolo não é uma alegoria nem um signo, ele é a imagem de um conteúdo, em sua maior parte transcendental ao consciente. $\bigcirc$ símbolo apenas é vivo enquanto cheio de significado (Jung,1961/2016). O símbolo concerne a nossa totalidade, é unificador de opostos, e pode atuar apenas na compreensão histórica ou filosófica.

fato de os sacerdotes religiosos do Taki Onkoy terem escolhido as huacas pré-incas Titicaca e Pachacamac como as principais huacas para serem ressuscitadas, gera algumas hipóteses sobre a simbologia arquetípica viva dentro delas e sua importância na vida psíquica do indígena. Como se as duas huacas tivessem crescido no inconsciente coletivo ao longo dos séculos, tornando-se sistemas psicoterapêuticos cheios de força e transformação no Taki Onkoy. 


\section{Huaca Titicaca: símbolo arquetípico da transformação e do herói criador}

Localizado no altiplano dos Andes, na fronteira entre Peru e Bolívia, o Lago Titicaca é o lago navegável mais alto do mundo e o segundo em extensão da América Latina. Desde os tempos antigos, o lago é considerado sagrado.

Mesmo com polêmicas e controvérsias a respeito das narrativas dos cronistas sobre as lendas de origem das dinastias dos governantes incas, o Lago Titicaca faz parte de uma das lendas mais conhecidas. Nela, o Titicaca é o local de nascimento dos incas e está associado à figura de um herói: o deus Wiracocha, herói primordial criador, que sai das profundezas do lago para criar os fundadores Manco Capac e Mama Ocllo (heróis humanos), na Ilha do Sol (De La Riva-Aguero, 1965).

No entanto, antes de sua incorporação pelos incas, o lago já era venerado por outras culturas, entre elas a cultura tiahuanaco que floresceu na região, aproximadamente entre os séculos II a.C. e VI d.C. $O$ deus principal dos tiahuanacotas também era Wiracocha, ou deus do báculo, que, de acordo com Rostworowski (2014), poderia ainda ser o deus Tunupa, dos reinos aymara posteriores.

Há evidências arqueológicas de que os tiahuanacotas consideravam o Lago Titicaca sagrado e realizavam uma série de rituais em sua homenagem. Esses ritos eram muito complexos e associados ao uso de substâncias alucinógenas, consumidas tanto por sacerdotes quanto por pessoas que seriam sacrificadas (Lumbreras e cols., 2008).

Segundo Alvarez (2013), ontologicamente a água, em sua essência, é pura. Simboliza a vida e a morte. Traz descanso e bem-estar. $O$ ser humano, como as águas do rio, morre a cada momento. A água também acompanha o simbolismo da transformação, é um catalisador e um elemento purificador.

Dentro do movimento Taki Onkoy, a huaca Titicaca cumpria a função simbólica de retornar à origem, resgatando as lendas e histórias míticas de heróis fundadores e deuses criadores.

Essas lendas e histórias míticas são muito mais complexas do que parecem e mantêm estruturas, níveis e interpretações simbólicas dos habitantes andinos. Como afirma Lévi-Strauss (1990), o mito é uma estrutura complexa que, por meio de processos de simplificação e simbolização de seus elementos, guarda um conteúdo que vai além da simples compreensão da mensagem linguística.

Resulta evidente que os seres mitológicos dessas histórias mantiveram uma grande importância para os nativos. Os símbolos arquetípicos que expressavam esses seres não perderam seu poder na mentalidade andina, seja pelo olhar da lenda inca, seja pelo olhar dos deuses ancestrais. Desaparecendo o eu ideal (o herói inca ou o Wiracocha, como um herói criador) com a conquista, a urgência de reunir a identidade comunal pelos mitos de origem é identificada com seus próprios heróis. 
Tanto Manco Capac como Wiracocha representam o herói que é confrontado com forças sobrenaturais e com suas próprias limitações e ganha uma vitória decisiva; o herói retorna de sua aventura fortalecido e cheio de presentes que recebeu em alguma fonte de poder. $\bigcirc$ mito do herói, às vezes, varia em conteúdo, mas a forma permanece e é exatamente a permanência da forma que facilita a identificação nos mitos dos povos e das culturas (Zacharias, 1998).

\section{Huaca Pachacamac: símbolo arquetípico da transformação e da abundância}

Pachacamac é um sítio arqueológico formado por vários edifícios e localizado na margem direita do Rio Lurín, perto do Oceano Pacífico (Possi-Escot, 2014). Nele, um antigo oráculo pré-hispânico, construído basicamente com tijolos de adobe, foi o principal local de culto do deus Pachacámac. O santuário é grande e espaçoso, com uma vista impressionante do oceano.

O culto de Pachacámac era o centro de toda a religião costeira porque o deus era considerado o responsável pela criação do universo e de tudo o que ele contém.

Pachacamac foi o principal santuário da costa central por mais de mil anos e seus templos eram visitados por multidões de peregrinos, durante os grandes rituais andinos, pois, Pachacámac era um oráculo de sucesso, capaz de prever o futuro e controlar os movimentos da Terra (Rostworowski, 2004).

No santuário de Pachacamac, pessoas de todos os Andes também procuravam soluções para seus problemas ou respostas para suas dúvidas. Os antigos andinos acreditavam que um único movimento da cabeça do deus Pachacámac causava terremotos. Ele também era o deus da abundância, da subsistência.

No mundo andino uma única palavra pode sintetizar vários conceitos, assim, o termo "pacha" significa indistintamente mundo-universo, isto é, matéria, tudo o que existe; a mesma palavra designa tempo, um fluxo perpétuo e unitário entre o passado e o futuro. Pode ser também uma referência direta ao elemento terra: a terra que se cultiva.

O termo "Kamaq" significa ordem, isto é, cosmos em espanhol, arquitetura primária de tudo o que existe. Em muitos estudos, "camac" ou "kamac" é concebido como energia vital.

Logo, "pacha+camac" pode ser então aquele que é responsável ou fonte de energia vital para a terra.

Nas culturas pré-incas, não era possível conceber o homem andino como separado da natureza. Especialmente na cultura inca, eles acreditavam em Pachamama (em alguns mitos considerada a esposa do Pachacámac) como a personificação da Mãe Terra. 
Dentro da psicologia analítica, Pachamama estaria associada ao arquétipo da Grande Mãe, símbolo muito presente em diferentes culturas, uma vez que, de um modo geral, a terra é o receptáculo de tudo o que existe, simboliza a mãe por sempre acolher seus filhos (Alvarez, 2013).

Quando os incas chegaram ao santuário de Pachacámac, eles respeitaram seu significado religioso e fundaram uma série de edifícios cerimoniais e administrativos, com os objetivos de promover o culto ao Sol e de estabelecer uma sede importante (Rostworowski, 1999).

É muito provável que os sacerdotes religiosos do movimento Taki Onkoy tenham escolhido a huaca do santuário de Pachacámac em razão de sua localização geográfica, de sua importância histórica como centro de peregrinação e, especialmente, pelos atributos do deus Pachacámac e pelo que ele simbolizava para o homem andino: o sagrado, o divino, o superior.

Mas o simbolismo do deus Pachacámac é muito complexo. Trata-se de um deus que se transformou dentro de uma misteriosa multiplicidade de funções: é o deus que prediz o futuro, controla os movimentos da Terra, concede subsistência. Assim, nele estão presentes os símbolos arquetípicos da vida e da criação.

Nas lendas e mitos do deus Pachacámac encontramos situações enigmáticas, mágicas, assassinatos e renascimentos, mas também há informação sobre uma época de abundância, de ordem social, de ricas oferendas, de boas relações entre deuses e homens, de fertilidade e fecundidade. Em meio à desapropriação psicológica sofrida pelos indígenas na época do Taki Onkoy, a huaca Pachacámac, simbolicamente, significaria a busca pelo retorno àquele paraíso imaginário de plenitude e harmonia.

Para Eeckhout (2004), além dos atributos abstratos do Pachacámac, ele é um deus terrestre e costeiro, seu nome significa terra, mundo, natureza, espaço e tempo. Ele simboliza o abraçar, conter, cingir, cercar, para embrulhar, cobrir, preservar ou nutrir, e era isso que pediam os indígenas que estavam atravessando o trauma da conquista. Na urgência de recuperarem a ordem das coisas e a unificação de suas almas fragmentadas, eles procuraram nascer de novo, e renascer significa retornar para aquele lugar protegido e emergir para uma nova vida.

\section{Dualidade e polaridade das huacas}

Para os andinos, a humanidade e a natureza se harmonizam e se adaptam para coexistir. A evolução dos mitos e do pensamento do homem andino aconteceu desde o início do período formativo. Trata-se de uma concepção própria, uma vez que a cultura andina não teve contato com nenhuma outra civilização do mundo, devido à sua geografia e a outros fatores sociais e climatológicos; seus conceitos eram muito diferentes daqueles dos europeus.

Um aspecto central da cosmovisão andina é o conceito de dualidade como princípio gerador e organizador do cosmos e da realidade: dia e noite, luz e 
escuridão, homem e mulher. $\bigcirc$ mundo inteiro é concebido e organizado seguindo as diretrizes da divisão em metades complementares (Llamazares, 2014). De acordo com essa concepção, tudo o que existe, seja um objeto real, seja um conceito abstrato, tem seu par, seu oposto, seu complemento. mundo andino como um todo é concebido sob uma dinâmica constante de opostos complementares que garantem a sobrevivência natural e social.

O conceito é bastante complexo porque inclui também concepções tais como a busca de equilíbrio, cooperação recíproca, trabalho conjunto e ação complementar. Dentro da visão de mundo dos Andes, a existência é definida como um processo dinâmico, no qual há um jogo incessante de polaridades, tensões lutas e unidades necessárias para a vida. Ávila, citado por Eeckhout (2004, p. 10), nos diz:

[...] os Ingas acreditavam que os limites da terra estavam em Titicaca e, do outro lado do mar, nas terras de Pachacamac; além não havia mais nada. Talvez por essa crença eles tenham adorado essas duas huacas mais do que todas as outras e levantado uma imagem do sol nas proximidades de Pachacamac "de baixo". E até hoje esse lugar se chama Punchaucancha.

A escolha das huacas Titicaca e Pachamac como as principais a serem ressuscitadas através dos rituais no Taki Onkoy também poderia significar unir simbolicamente o limite do mar (Pachacamac) com o limite do céu (Titicaca), as terras altas (Titicaca) com as terras baixas (Pachacamac), a costa (Pachacamac) com a serra (Titicaca), o Sol (Titicaca) com a Lua (Pachacamac), o fogo (Titicaca) com a terra (Pachacamac) e o dia (Titicaca) com a noite (Pachacamac), em oposições binárias e de dualidade, como huacas em constante transformação e complementaridade, cujas energias arquetípicas estavam impressas na psique do habitante andino.

\section{Considerações finais}

A violência desencadeada nos séculos $X V I$ e XVII foi quase indescritível, o cosmos e as relações entre os seres humanos nos Andes pré-hispânicos foram severamente afetados. Muitos foram os motivos de confusão e rebelião nos Andes e, dentre eles, consideramos dois como principais: a tentativa dos primeiros conquistadores de querer fazer escravos indígenas e a evangelização católica dos indígenas, que os afrontava em suas crenças, sua visão de mundo, suas práticas culturais e sociais e os forçava a aceitar uma realidade que fazia pouco ou nenhum sentido para eles.

Os padres católicos exerceram dois níveis conceituais de violência. $\bigcirc$ primeiro foi a destruição das huacas, para subjugar as populações, pois eles conheciam seu tremendo peso simbólico-religioso (Brosseder, 2008). O segundo tem a ver com a violência de transformar indivíduos, pela força, em católicos. Nesse sentido, a punição daqueles que persistiam no erro da idolatria era executada 
sem misericórdia; o idólatra não era considerado humano, tratava-se de objeto para o qual a força da justiça deveria ser dirigida.

É nesse contexto que o movimento Taki Onkoy surge como a primeira rebelião andina contra o domínio espanhol com base cultural e espiritual, com práticas simbólico-religiosas que incluíam jejuns, canções, cerimônias, rituais e danças escatológicas.

Este trabalho tentou, embora em parte, seguir as teorias de Carl G. Jung, revelando os símbolos míticos aniquilados pela conquista - por isso, achamos importante tratar do que foi levantado no encontro de dois mundos e entender os complexos processos psicológicos e corporais que giravam em torno do movimento Taki Onkoy. Dessa forma, foi preciso penetrar na essência dos símbolos arquetípicos e naquilo que os sacerdotes e participantes do movimento queriam recuperar deles.

Uma característica essencial da obra de Jung, e que a diferencia de outros analistas, é a apreciação das raízes e o respeito pela história e pelas pessoas que nos precederam. Nesse sentido, os indígenas do movimento Taki Onkoy procuraram recuperar sua identidade, retornando às suas origens, abraçando os elementos ancestrais (simbolicamente, por meio das huacas Titicaca e Pachacamac) e respeitando os primeiros deuses de sua cosmovisão. As huacas expressavam-se nos corpos dos indígenas; a dança e o canto eram o caminho para entrar no mundo inconsciente.

As ações propostas pelos sacerdotes do Taki Onkoy foram uma forma de cura e de libertação diante da opressão. Considerando que a desapropriação de seus deuses e crenças tratou-se de um trauma na vida dos indígenas, aqui podemos dizer que o trauma passou da psique para o corpo. No Taki Onkoy fez-se uma tentativa de incorporar e aliviar os sofrimentos, os complexos e as fragmentações que foram gerados nesse processo.

Os povos indígenas do movimento Taki Onkoy ativaram um sistema arquetípico de preservação da psique, usando seus conhecimentos ancestrais, por meio de processos simbólicos e da dança coletiva. Essas danças mobilizavam fenômenos inconscientes que chegavam à fusão das consciências individuais em um grupo, e fortaleciam os laços de pertencimento, que uniam as pessoas e retornavam ao corpo. Aqui o divino fundia-se com o corpóreo e com as forças arquetípicas, como Jung explica em seu extenso trabalho.

De acordo com Jung (1937/2014), o processo de individuação e a alta valorização da estética da sociedade Ocidental moderna geraram uma ruptura do corpo com seu aspecto divino. Acrescentamos a isso os aspectos repressivos impostos pela sociedade ao corpo, que o tornaram algo escuro e intocável, parte da sombra da pessoa. No Taki Onkoy, como em outras religiões, os rituais coletivos da dança extática eram formas pelas quais o corpo tornava-se particularmente intenso, veículo prático, direto e eficaz da comunicação religiosa. A capacidade simbólica do corpo fundia-se com a 
divindade, surgindo uma sensação de salvação, de libertação espiritual, de poder de transformação próprio das huacas.

No Taki Onkoy tudo voltava ao corpo, a dança em êxtase era a representação coletiva inconsciente, onde estavam subjacentes os símbolos arquetípicos, os deuses, os mitos. A dança extática era o caminho para a totalidade, para o equilíbrio perdido. Constituiu uma dança e um canto para todos; uma agitação violenta de "presenças" que interagiam e se alimentavam mutuamente. Através de uma atividade corporal frenética e paroxística, os indivíduos eram purificados de toda a contaminação e de todo o mal e voltavam a possuir seu próprio ser e seus próprios símbolos.

\section{Referências}

Alvarez, A. (2013). Dicionário de imagens, símbolos, mitos, termos e conceitos Bachelardianos. Londrina: Eduel.

Brosseder, C. (2008). El poder de la huacas: cambios y resistencia en los Andes del Perú colonial. Arequipa: Ediciones El Lector S.R.L.

Campbell, J. (2008). Mito e transformação (F. N. Ramos, trad.). São Paulo: Agora.

Cavero, R. (2001). Los dioses vencidos: una lectura antropologica del Taki Onqoy. Ayacucho: Universidad Nacional San Cristobal de Huamanga.

Curatola, M. (1987). Discurso abierto sobre los cultos de crisis: versión revisada de la primera parte de un "nuevo mundo" (Tesis). Pontificia Universidad Católica del Perú, Lima.

Almeida, V. (2011). Movimento expressivo: a integração psicofísica através do movimento. In E. B. Zimmermann (Org.), Corpo e individuação (pp. 15-38, $2^{a}$ ed.). Petrópolis, RJ: Vozes.

De La Riva-Aguero, J. (1965). Las civilizaciones primitivas y el imperio incaico. Lima: Fondo Editorial de la Pontificia Universidad Católica del Perú.

Eeckhout, P. (2004). Relatos míticos y prácticas rituales en Pachacamac. Bulletin de I'Institut Français d'Études Andines, 33 (1): 1-54. https://doi.org/10.4000/bifea.5786,

González Holguín, D. (1952). Vocabulario de la Lengva General de todo el Perv llamada Lengva Qquichua o del Inca. Lima: [s.n.]. (Trabalho original publicado em 1608).

Guamán Poma, F. (1615). Primer nueva crónica y buen gobierno. Copenhague: Biblioteca Real de Dinamarca.

Hard, R. (2008). El gran libro de la mitología griega: basado en el manual de mitología griega de H. J. Rose. Madrid: La Esfera de los Libros.

Jacobi, J. (2016). Complexo, arquétipo e símbolo na psicología de C.G. Jung. Petrópolis, RJ: Vozes. 
Jung, C. G. (2014). Arquétipos e o inconsciente coletivo. In Os arquétipos e o inconsciente coletivo. (OC, Vol. IX/1, 2a ed., pp. 51-63). Petrópolis, RJ: Vozes. (Trabalho original publicado em 1937).

Jung, C. G. (Org.). (2016). O homem e seus símbolos (M. L. Pinho, trad.). Rio de Janeiro: Nova Fronteira. (Trabalho original publicado em 1961).

Llamazares, A. (2014). Metáforas de la dualidad en los Andes: cosmovisión, arte, brillo y chamanismo. Buenos Aires: Consejo Nacional de Investigaciones Científicas y Tecnológicas.

Lévi-Strauss, C. (1990). Mito y significado. Madrid: Alianza Editorial.

Lumbreras, L. G., Kaulicke, P., Santillana, J. I., y Waldermar E. (2008). Compendio de historia económica del Perú: economía prehispánica. Lima: Banco Central de Reserva del Perú.

Millones, L. (2007). Mesianismo en América Hispana: el taki onkoy. Memoria Americana, (15), 7-39.

Montani, R., y Paéz, T. (2008). El taqui onkoy: "del silencio al canto mesiánico". Lima: Perspectivas Latinoamericanas.

Possi-Escot, D. (2014). Pachacamac: conservación en arquitectura de tierra. Lima: Ministerio de Cultura del Perú.

Rostworowski, M. (1999). El señorío de Pachacamac: el Informe de Rodrigo Cantos de Andrade de 1573. Lima: IEP.

Rostworowski, M. (2004). La influencia Wari en el incario y las peregrinaciones. Boletín de Arqueología PUCP, (8), 23-30.

Rostworowski, M. (2014). Historia del Tahuantinsuyu. (OC, Vol. VIII). Lima IEP.

Rostworowski, M. (2017). Aproximación psicoantropológica a los mitos andinos. Lima: IEP.

Vernant, J. P. (1999). El universo; los dioses; los hombres: el relato de los mitos griegos (J. Jordó, trad.). París: Sevil.

Zacharias, J. J. M. (1998). Ori axé: a dimensão arquetípica dos orixás. São Paulo: Vetor.

Minicurrículo: Sandra Morales - mestre em Gerência Social pela Universidade Católica de Santa María (Peru); especialista em Terapias Corporais e Artísticas baseadas na Psicologia Analítica pela Universidade Paulista - UNIP; graduada em Psicologia pela Universidade de San Agustín (Peru). Faz parte do Departamento Alma Brasileira da Associação Junguiana do Brasil e do Coletivo Equipe de Base Warmis - Convergência das Culturas. São Paulo/SP. E-mail: sandrapaolam@hotmail.com 